\title{
The Relation between Public Managers' Compensation and Governance
}

\author{
Mario Coccia (Corresponding author) \\ CNR - National Research Council of Italy, Via Real Collegio, 30-10024, Moncalieri \\ (TO), Italy; Arizona State University, Center for Social Dynamics and Complexity, \\ Engineering Center A, 1031 S. Palm Walk, Tempe, AZ 85281-2701, Italy \\ E-mail: mario.coccia@cnr.it \\ Igor Benati \\ CNR -- National Research Council of Italy, Via Real Collegio, 30-10024, Moncalieri \\ (TO), Italy
}

Received: Jan. 12, 2018 Accepted: Feb. 11, 2018 Online published: Mar. 20, 2018

doi:10.5296/jpag.v8i1.12469

URL: https://doi.org/10.5296/jpag.v8i1.12469

\begin{abstract}
A vast literature in the field of public organizations has analyzed several factors of the compensation of government senior managers. However, the institutional factors associated with high levels of compensation of public managers are hardly known. In particular, studies about the possible relation between factors of governance and compensation of public managers are scarce. The statistical evidence here reveals that in the OECD countries, high levels of compensation for central government senior manager (standardized with GDP per capita) seem to be associated with low government effectiveness, low regulatory quality, low freedom, low rule of law and control of corruption (in short, bad governance). These results suggest insights for general reforms of governance aimed to support equitably levels of compensation of public managers and efficiency of public institutions.
\end{abstract}

Keywords: compensation, public managers, governance, pay, salary, high public office, government effectiveness, regulatory quality, control of corruption

JEL Classification: D73; H0; J30; J33; J45, M12; M52 


\section{Introduction}

Public managers and bureaucrats play a central role in the public administration of countries (Peters and Pierre, 2016; Hood and Dixon, 2015; Coccia, 2014) ${ }^{1}$. However, the public sees the compensation of public managers disproportionate and inequitable in relation to their activity and achievements in public organizations (Benati and Coccia, 2017; 2018). Gao and Li (2015) show that Chief Executive Officers (CEOs) in public firms are paid 30 per cent more than CEOs in comparable privately-held firms. In general, the hot debate, both in scientific literature and in media, is that government managers are overpaid (Hood and Peters, 2003; Hood and Peters, 1994; cf., Jarque, 2008). Several studies have analyzed different factors of the high compensation of high public officials (cf., Chen and Bozeman, 2014; Hood and Lodge, 2006). In particular, these studies show that compensation of public managers can depend on economic, social, institutional and political factors of countries (Benati and Coccia, 2017). Studies of public economics and public administration unveiled many aspects of the compensation for high public office ${ }^{2}$, showing how political and institutional elements may be more significant factors than economic ones in explaining the level and growth of salary for high public officials (Brans and Peters, 2012; Hood and Peters, 1994; Hood and Peters, 2003; Benati and Coccia, 2017).

In this research field, the present study endeavors to shed some empirical light on the relationship between the factors of governance of countries and compensation for high public officials. Specifically, the study explains, whenever possible how some indicators of governance between the Organisation for Economic Co-operation and Development (OECD) countries can affect levels of compensation for public managers. In order to position this analysis, the next section presents the theoretical framework of this study.

\section{Theoretical Framework}

Governance has a critical role for human resources (North et al. 2008; Keser and Gökmen, 2017). Currently, there is no a unique theoretical pattern of good governance for human development because of different institutional contexts and resources endowments within countries. New institutional economics shows that governance affects efficiency and accountability of the involved subjects and political negotiations of their voices (North et al., 2008).Two alternative strategies for the development within countries are: the "market enhancing governance" and the "growth enhancing governance" (Khan, 2009). However, Sundaram and Chowdhury (2013) argue that there is no general empirical evidence on causal relations from governance to human development. At operational level, positive relations between governance and human development are due to good governance to maintain economic productive structures (Coccia and Rolfo, 2007; Benati and Coccia, 2017).

One of the problems in public economics and public administration is to detect the factors associated with high levels of compensation for high public officials (Hood and Peters, 1994; Hubbard, 2005). Many studies on compensation of public managers explain some

${ }^{1}$ Cf. also, Bozeman, 2007; Jarque, 2008; Coccia, 2005, 2007, 2013

${ }^{2}$ Hood and Lodge, 2006; Coccia and Benati, 2017; cf., Coccia, 2009b, 2010, 2017, 2017a 
components of salary and support reforms directed to increase the efficiency of public organizations as well as of overall public administration (Chen and Bozeman, 2014; Gao and Li, 2015; Malul and Shoham, 2013; Rimington, 2008; cf., Coccia and Rolfo, 2007, 2010, 2013; Coccia and Cadario, 2014). In general, the average compensation of managers has risen in recent years both in public and private sectors (Benati and Coccia, 2017; Jarque, 2008). However, the economic crisis started in 2008 and social problems in Europe have led several governments and regulators to reform the public institutions and compensation packages in public sector in order to control the dynamics of salaries and the government debt of nations (cf., Butkiewicz and Yanikkaya, 2011; Dittmann et al., 2011; Kuhnen and Niessen, 2012; cf., Coccia, 2017).

The high compensation of high public officials is due to manifold factors. Many scholars claim that labor market determines different levels of compensation and in some countries the trade unions in public companies tend to influence contracts and level of salaries (cf., Hubbard, 2005). The ownership structure of (public or private) companies can also affect the compensation of managers and their executive power (Denis et al., 1997). Malul and Shoham (2013, p. 75) identify some reasons of the huge differences in compensation of Chief Executive Officers (CEOs). In particular, CEOs take advantage of the non-competitive market structure of the public sector (also based on monopolies and natural monopolies) to have high salaries (cf., Meier and O’Toole, 2010; Coccia and Rolfo, 2009).

Studies also show how economic and organizational factors play an important role in determining rewards for public officials and bureaucrats (Hood and Lodge, 2006; Coccia and Benati, 2017; Benati and Coccia, 2018; cf., Coccia, 2009, 2009a, 2009b, 2010, 2017a). In particular, this literature has analyzed political and institutional factors of the compensation of public managers (Benati and Coccia, 2017; Coccia and Benati, 2017). Nevertheless, the relation between governance and salaries of public managers is almost unknown.

The concept of governance has a plurality of meanings. Fukuyama (2013) claims that governance is the government's ability to make and enforce rules and to deliver services. Governance is the power exercised in the management of a country's economic and social resources for development (World Bank, 1992). The World Bank (2017) also defines governance as "a process within a given set of rules (formal and informal) that shapes and is shaped by power" to implement policies. Good governance for development consists of many elements, such as democracy, human rights, rule of law, effective management, transparency/accountability and a mix of socioeconomic policies (Gisselquist, 2012). New institutional economics defines governance as a system of political institutions, state capacity, and regulation of these institutions that improves efficiency and human well-being.

In more practical terms, governance can be defined as traditions and institutions by which authority in a country is exercised (Kaufmann et al., 1999). Governance, specifically, has three dimensions:

- the political dimension - processes by which those in authority are selected, elected, monitored and replaced 


\section{Macrothink}

- the economic dimension - process by which public resources are effectively managed and sound policies implemented

- the institutional dimension - processes by which citizens and the state itself respect the society's/public institutions.

In general, the measurement of governance is a difficult work. Many studies have suggested measures of governance and applied them in both research and policy-making processes (Gisselquist, 2014). In this research field, Kaufmann et al. (2010) have implemented a structured system to measure governance, the so-called Worldwide Governance Indicators (WGI). The WGI system consists of six composite indicators: Voice and Accountability, Political Stability and Absence of Violence/Terrorism, Government effectiveness, Regulatory Quality, Rule of Law and Control of Corruption (Kaufmann et al., 2010). The WGI indicators draw together data on perceptions of governance from a wide variety of sources: surveys of firms and households, as well as the subjective assessments of a variety of commercial business information providers, non-governmental organizations, and a number of multilateral organizations and other public sectors. These indicators can be important to identify good governance and bad governance within and between countries (Benati and Coccia, 2017; Coccia and Benati, 2017).

Good governance is a normative approach to identify the rules that have to be fulfilled by subjects participating in public decision-taking. In general, principles of good governance refer to a list of common principles that are useful and important to improve decision-making processes, to strengthen democracy and to improve social and economic development of countries.

Empirical evidence shows that, on the whole, good governance and institutions are correlated with higher economic growth, human development and better historical development paths of countries (Acemoglu, 2008; Coccia, 2010a). On the contrary, bad governance can lead to inefficient public organizations, which can also determine negative effects on human resources and possibly economic growth of nations (Coccia, 2005, 2007). Overall, then, levels of salaries for top-level public managers can be also affected by economic governance of countries (cf., Benati and Coccia, 2017; Coccia and Benati, 2017). This theoretical framework, described here, can support a working hypothesis that is presented in the next section. 


\section{Methods and Materials}

Figure 1 shows the conceptual model of the study here underpinned in the theoretical framework described in previous section.

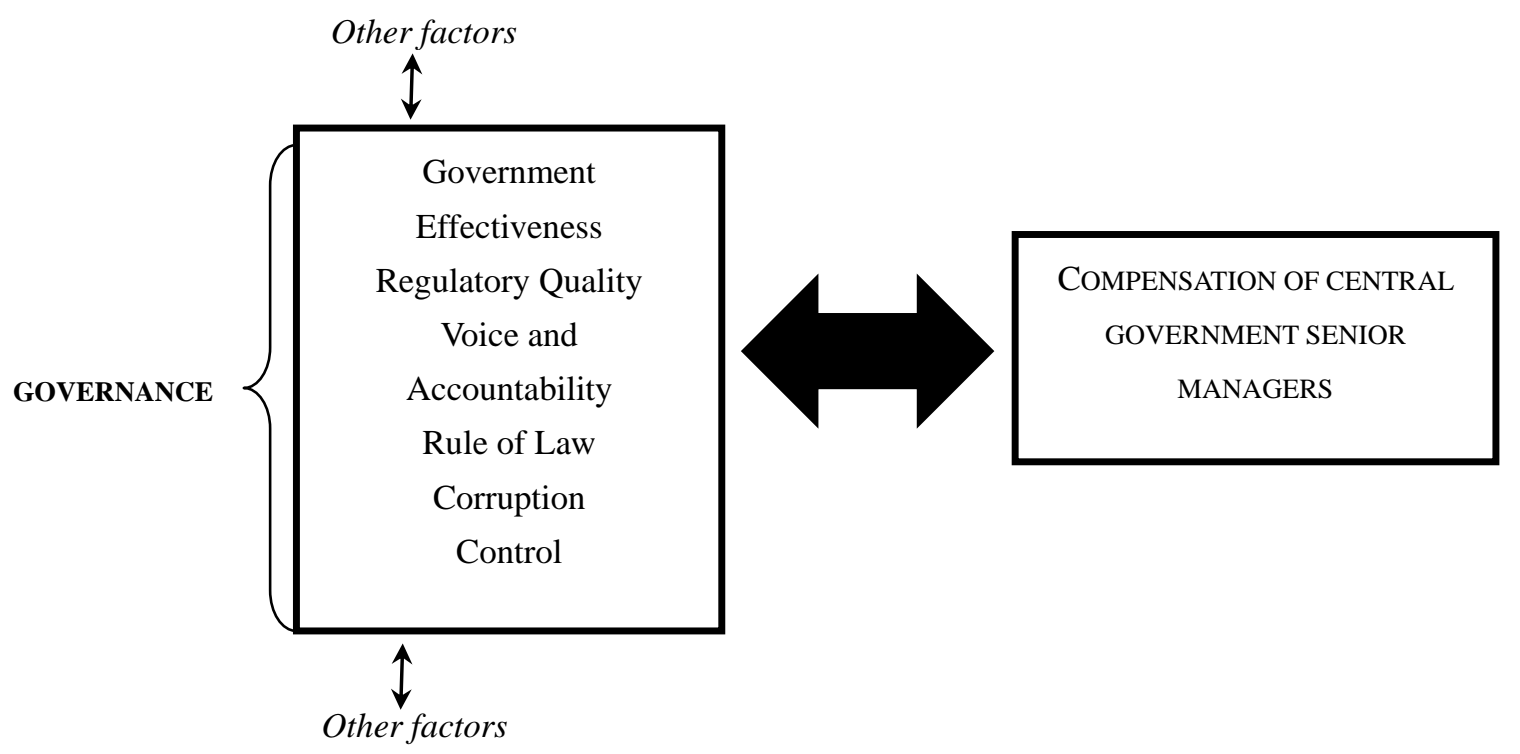

Figure 1. Model of the relation between average levels of annual compensation of central government senior managers and governance factors of countries.

\subsection{Working Hypothesis}

This model points out the following working hypothesis $(H P \phi)$ :

$H P \phi$ : average level of governance can affect the average level of compensation for public managers between countries, other things being equal.

The purpose of the present study is to see whether statistical evidence supports the hypothesis $(\mathrm{HP} \phi)$ that high levels of compensation for central government senior manager are associated with bad governance of countries, which is due to low government effectiveness, regulatory quality, freedom, rule of law and control of corruption of countries (and vice versa).

\subsection{Sample and Sources of Data}

The sample under study here is a set of OECD countries given by: Australia, Austria, Belgium, Denmark, Estonia, Finland, France, Germany, Greece, Italy, Netherlands, Poland, Portugal, Slovak Republic, Slovenia, Spain, Sweden, United Kingdom, United States, and New Zealand. Data of many countries are not available; however this small sample is a main starting point to show preliminary analysis of general trends and causes concerning the relation under study.

Sources of data are the OECD (2013), the World Bank (2008) and the Worldwide Governance Indicators (WGI, 2010; cf., Norris, 2008). 


\section{$\Lambda$ Macrothink}

\subsection{Measures}

The variables of this study here are in Table 1 .

Table 1. Variables and sources of data

\begin{tabular}{|c|c|}
\hline Description & Source \\
\hline $\begin{array}{l}\text { Compensation of public managers } \\
\text { - Average annual compensation of central government senior managers, } \\
\text { D1 position, USD PPP (at country level) } 2011\end{array}$ & OECD 2013 \\
\hline $\begin{array}{l}\text { Economic indicator } \\
\text { - GDP per capita PPP constant international \$ } 2005\end{array}$ & World Bank 2008 \\
\hline $\begin{array}{ll} & \text { Governance indicators } \\
\text { - Kaufmann government effectiveness } 2006 \\
\text { - Kaufmann regulatory quality } 2006 \\
\text { - Kaufmann voice and accountability } 2004 \\
\text { - Kaufmann rule of law } 2004 \\
\text { - Kaufmann corruption control } 2004\end{array}$ & $\begin{array}{l}\text { WGI (Norris, 2008) } \\
\text { WGI (Norris, 2008) } \\
\text { WGI (Norris, 2008) } \\
\text { WGI (Norris, 2008) } \\
\text { WGI (Norris, 2008) }\end{array}$ \\
\hline
\end{tabular}

Note: The OECD is Organisation for Economic Co-operation and Development; WGI is Worldwide Governance Indicators by the World Bank (2008).

The first indicator under study is the compensation of senior managers that have a main role in government policy making and execution. In particular, this study focuses on D1 managers that are top public officials below the minister or Secretary of State. They can be a member of the senior civil service and/or appointed by the government or head of government. They advise government on policy matters, oversee the interpretation and implementation of government policies and, in some countries, have executive powers. D1 managers may be entitled to attend some Cabinet/Council of ministers meetings, but they are not part of the Cabinet/Council of ministers. They provide overall direction and management to the ministry/Secretary of State or a particular administrative area. Of course, the precise job title can differ across countries (OECD, 2012).

This study also considers levels of Gross Domestic Product (GDP) per capita to standardize the annual compensation of central government senior manager between countries.

In order to investigate the relation between compensation of public managers and governance, a number of measures of the quality of governance is considered from Worldwide Governance Indicators (cf., Thomas, 2010). In particular, the capacity of government to effectively formulate and implement policies is measured by (Kaufmann et al., 2008; 2005):

- Government Effectiveness (GE) - capturing perceptions of the quality of public services, the quality of civil service and the degree of its independence from political pressures, the quality of policy formulation and implementation, and the credibility of the government's commitment to such policies.

- Regulatory Quality (RQ) - capturing perceptions of the ability of government to formulate and implement sound policies and regulations that permit and promote private sector development. 
Remark: indices of Government Effectiveness (GE) and Regulatory Quality (RQ) are considered in the year 2006, which is the last year available in the dataset under study (Norris, 2008). This dataset also shows that these indicators have stable trends over time.

In addition, this study considers the indices of Kaufmann voice and accountability, rule of law and control corruption to explain some possible determinants of the levels of compensation of public managers in the OECD countries. In particular,

- Kaufmann Voice and Accountability index captures perceptions of the extent to which a country's citizens are able to participate in selecting their government, as well as freedom of expression, freedom of association, and a free media (Kaufmann et al., 1999; 2005; 2008).

- Kaufmann Rule of Law- capturing perceptions of the extent to which agents have confidence in and abide by the rules of society, and in particular quality of contract enforcement, property rights, police, and courts, as well as the likelihood of crime and violence.

- Finally, Kaufmann Control of Corruption - capturing perceptions of the extent to which public power is exercised for private gain, including both petty and grand forms of corruption, as well as "capture" of the state by elites and private interests.

These data are from Worldwide Governance Indicators -WGI-(Kaufmann et al., 2008; Kaufmann et al, 1999; Norris, 2008; WGI, 2010).

\subsection{Data Analysis Procedure}

Database has undergone a horizontal and vertical cleaning, removing some countries with missing values. Then the normal distribution of variables has been checked with Kurtosis and Skewness coefficients and skewed variables were ln-transformed before including in statistical analyses to perform a comparative study (cf., Coccia and Benati, 2018).

The annual compensation of central government senior managers 2011 divided by GDP per capita 2005 (this ratio is called RCM) is calculated to compare the results across countries in a homogenous framework. The relationships between variables are analyzed with descriptive statistics and correlation analyses. In addition, the hierarchical cluster with squared Euclidean distance and Ward's method linkage is also applied to detect and analyze homogenous sets of countries that have a similar behavior concerning the Government Effectiveness (GE) and Regulatory Quality (RQ). The sets of this hierarchical cluster, based on government effectiveness and regulatory quality, are analyzed with descriptive statistics to understand differences of the level of annual compensation of central government senior managers associated with Kaufmann voice and accountability, rule of law and control of corruption between countries (governance indicators).

This study also applies a geospatial analysis on compensation of public managers combined with governance factors of countries. Firstly, the annual compensation of central government senior managers 2011 divided by GDP per capita 2005 (this ratio is called RCM) is calculated to standardize the levels between countries for creating a comparable framework. 


\section{I Macrothink}

Journal of Public Administration and Governance ISSN 2161-7104 2018, Vol. 8, No. 1

Secondly, the association between RCMi and governance indicators of country $i$ (ASC $i$ ) is given by:

ASCi $=\left(\mathrm{RCM}_{i}\right) \times(1 /$ Kaufmann Voice and Accountability Index $i \times$ Kaufmann Rule of Law Index $_{i} \times 1 /$ Kaufmann Control of Corruption Index $\left.{ }_{i}\right) ; \quad i=$ country, with $i=1,2, \ldots, n$ [1]

Remark: Governance indicators (Kaufmann Voice and Accountability, Kaufmann Rule of Law and Kaufmann Control of Corruption) in equation [1] are constructed to indicate positive effects with low levels of association (an indicator of good governance), whereas negative effects are given by high levels of association (a proxy of bad governance within countries).

The percentiles $25^{\text {th }}, 50^{\text {th }}$ and $75^{\text {th }}$ of the distribution of the association ASC $i$ are calculated to divide countries $i$ in four categories:

1) ASC $i \leq$ percentile $25^{\text {th }}$ (countries with low association)

2) percentile $25^{\text {th }}<$ ASC $i \leq$ percentile $50^{\text {th }}$ (countries with moderate association)

3) percentile $50^{\text {th }}<\mathrm{ASC} i \leq$ percentile $75^{\text {th }} \quad$ (countries with high association)

4) $\mathrm{ASC} i>$ percentile $75^{\text {th }}$ (countries with very high association)

A world map visualizes each country according to the categories just mentioned to which it belongs.

Low association indicates good governance factors of the country $i$ that can reduce the level of the annual compensation of central government senior managers divided by GDP per capita. High spatial association indicates bad governance that may increase the standardized level of annual compensation of central government senior managers (called RCM).

The expectation of these statistical analyses is that high levels of RCMi are also due to bad governance within countries. All statistical analyses are performed with the Statistics Software SPSS $®$. In particular, the geospatial analysis is based on Graphboard Template Chooser in SPSS version 24. Overall, the results of these analyses could be helpful to detect differences of the compensation of public managers between countries due to their dissimilar governance backgrounds.

\section{Results}

Table 2 shows a negative association between RCM (annual compensation of central government senior managers / GDP per capita PPP in \$) and LN Kaufmann government effectiveness ( $r=-0.598, p$-value $<0.01)$, LN Kaufmann regulatory quality $(r=-0.414$, $p$-value $<0.1)$, but also with LN Kaufmann law $(r=-0.593$, $p$-value $<0.01)$ and LN Kaufmann Control Corruption ( $r=-0.620, p$-value $<0.01)$.

Figure 2 shows the scatter of data, considering the variable government effectiveness $(G E)$ on RCM. Countries are located in four main sets with different behavior. In particular,

- countries High-High (H-H) GE are in upper-right section of figure 2: countries with high 
ratio of annual compensation of central government senior managers/ GDP per capita (RCM) and high government effectiveness (e.g., New Zealand, Australia, etc.)

- countries High - Low (H-L) GE are in lower-right section: countries with high RCM and low government effectiveness (e.g., Poland, Italy, etc.)

- countries Low-Low (L-L) GE are in lower-left section: countries with low RCM and low government effectiveness (e.g., Greece, Spain, etc.)

- countries Low-High (L-H) GE are in upper-left section: countries with low RCM and high government effectiveness (e.g., Germany, Denmark, Finland, etc.). This set may represent virtuous countries in terms of government effectiveness associated with a moderate level of RCM.

Table 2. Correlations

\begin{tabular}{|c|c|c|c|c|c|c|c|}
\hline & & $\begin{array}{c}\mathrm{LN} \\
\mathrm{RCM}^{(1)}\end{array}$ & $\begin{array}{c}\text { LN } \\
\text { Kaufmann } \\
\text { voice }\end{array}$ & $\begin{array}{c}\text { LN } \\
\text { Kaufmann } \\
\text { Law }\end{array}$ & $\begin{array}{c}\text { LN } \\
\text { Kaufmann } \\
\text { Control } \\
\text { Corruption } \\
\end{array}$ & $\begin{array}{c}\text { LN } \\
\text { Kaufmann } \\
\text { government } \\
\text { effectiveness }\end{array}$ & $\begin{array}{l}\text { LN } \\
\text { Kaufmann } \\
\text { regulatory } \\
\text { quality }\end{array}$ \\
\hline $\mathrm{LN} \mathrm{RCM}^{(1)}$ & $\begin{array}{l}\text { Pearson } \\
\text { Correlation } \\
\text { Sig. (2-tailed) } \\
\text { N }\end{array}$ & 20 & & & & & \\
\hline $\begin{array}{l}\text { LN Kaufmann } \\
\text { voice }\end{array}$ & $\begin{array}{l}\text { Pearson } \\
\text { Correlation } \\
\text { Sig. (2-tailed) } \\
\mathrm{N}\end{array}$ & $\begin{array}{r}-.443 \\
.050 \\
20\end{array}$ & 20 & & & & \\
\hline $\begin{array}{l}\text { LN Kaufmann } \\
\text { Rule of law }\end{array}$ & $\begin{array}{l}\text { Pearson } \\
\text { Correlation } \\
\text { Sig. (2-tailed) } \\
\mathrm{N}\end{array}$ & $\begin{array}{r}-.593^{* \pi} \\
.006 \\
20\end{array}$ & $\begin{array}{r}.901^{\pi / \pi} \\
.001 \\
20\end{array}$ & 20 & & & \\
\hline $\begin{array}{l}\text { LN Kaufmann } \\
\text { Control } \\
\text { Corruption }\end{array}$ & $\begin{array}{l}\text { Pearson } \\
\text { Correlation } \\
\text { Sig. (2-tailed) } \\
\text { N }\end{array}$ & $\begin{array}{r}-.620 \\
.004 \\
20\end{array}$ & $\begin{array}{r}.001 \\
20\end{array}$ & $\begin{array}{r}.001 \\
20\end{array}$ & 20 & & \\
\hline $\begin{array}{l}\text { LN Kaufmann } \\
\text { government } \\
\text { effectiveness }\end{array}$ & $\begin{array}{l}\text { Pearson } \\
\text { Correlation } \\
\text { Sig. (2-tailed) } \\
\text { N }\end{array}$ & $\begin{array}{r}-.598^{*-4} \\
.005 \\
20\end{array}$ & $\begin{array}{r}.001 \\
20\end{array}$ & $\begin{array}{r}.001 \\
20\end{array}$ & $\begin{array}{r}.001 \\
20\end{array}$ & 20 & \\
\hline $\begin{array}{l}\text { LN Kaufmann } \\
\text { regulatory } \\
\text { quality }\end{array}$ & $\begin{array}{l}\text { Pearson } \\
\text { Correlation } \\
\text { Sig. (2-tailed) } \\
\text { N }\end{array}$ & $\begin{array}{r}.070 \\
20\end{array}$ & $\begin{array}{r}.001 \\
20\end{array}$ & $\begin{array}{r}.001 \\
20\end{array}$ & $\begin{array}{r}.001 \\
20\end{array}$ & $\begin{array}{r}.001 \\
20\end{array}$ & 20 \\
\hline
\end{tabular}

**Correlation is significant at the $1 \%$ level (2-tailed). *Correlation is significant at the $10 \%$ level (2-tailed).

Note: (1) RCM= annual compensation of central government senior managers 2011 divided by GDP per capita 2005 


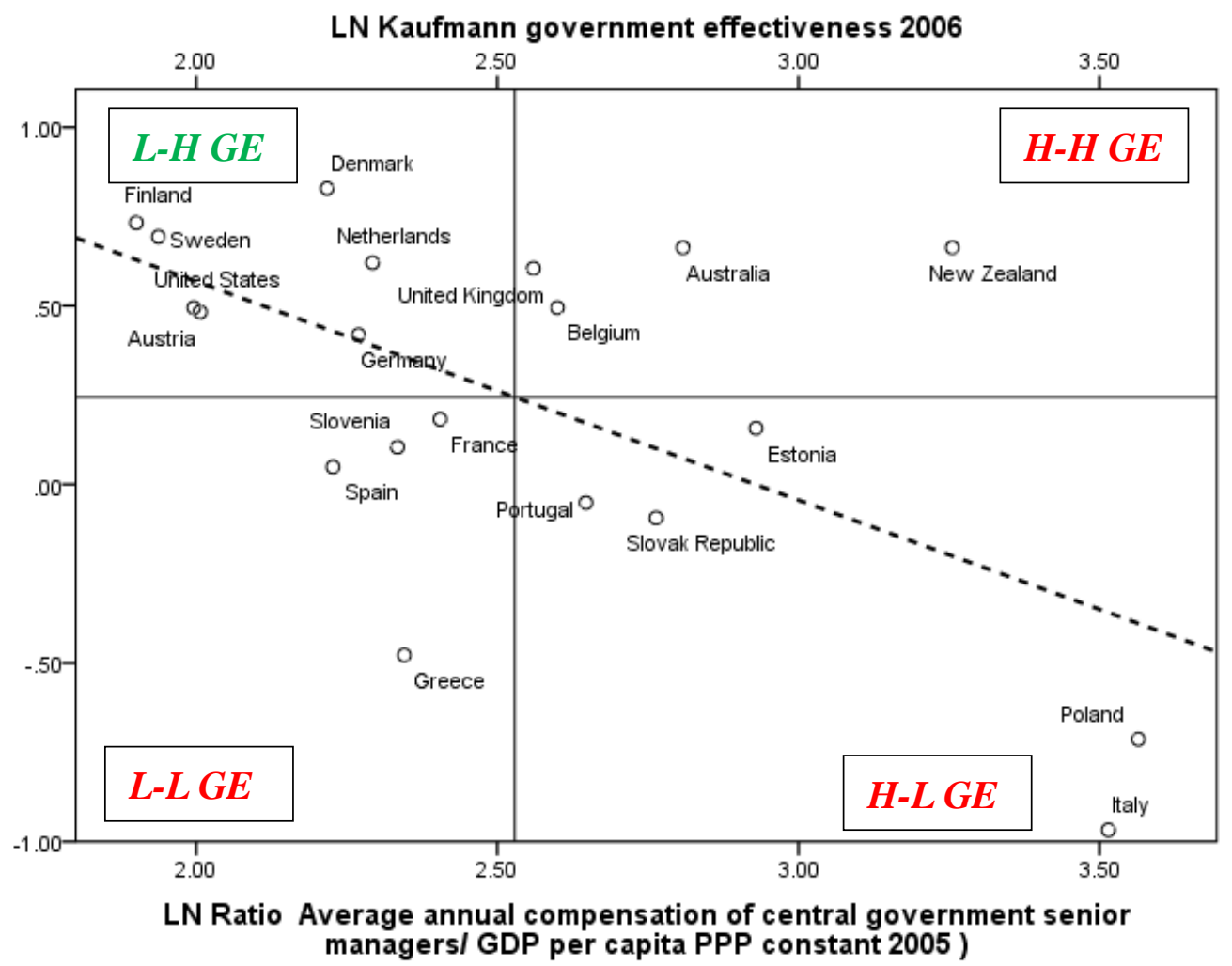

Figure 2. Relationship of the Kaufmann government effectiveness on Ratio annual compensation of central government senior managers/ GDP per capita (RCM)

Figure 3 shows the scatter of data considering the variable regulatory quality $(R Q)$ on RCM. Main groups of countries are given by:

- countries High-High $(H-H) R Q$ are in upper-right section of Figure 3: countries with high Ratio RCM (annual compensation of central government senior managers/ GDP per capita) and high regulatory quality (e.g., New Zealand, Australia, etc.)

- countries High -Low $(H-L) R Q$ are in lower-right section: countries with high RCM and low regulatory quality (e.g., Poland, Italy, etc.)

- countries Low-Low ( $L-L) R Q$ are in lower-left section: countries with low RCM and low regulatory quality (e.g., Greece, Spain, France, etc.)

- countries Low-High (L-H) $R Q$ are in upper-left section: countries with low RCM and high regulatory quality (e.g., Germany, Denmark, Finland, Austria, etc.). This set may represent virtuous countries in terms of regulatory quality associated with a moderate level of RCM. 


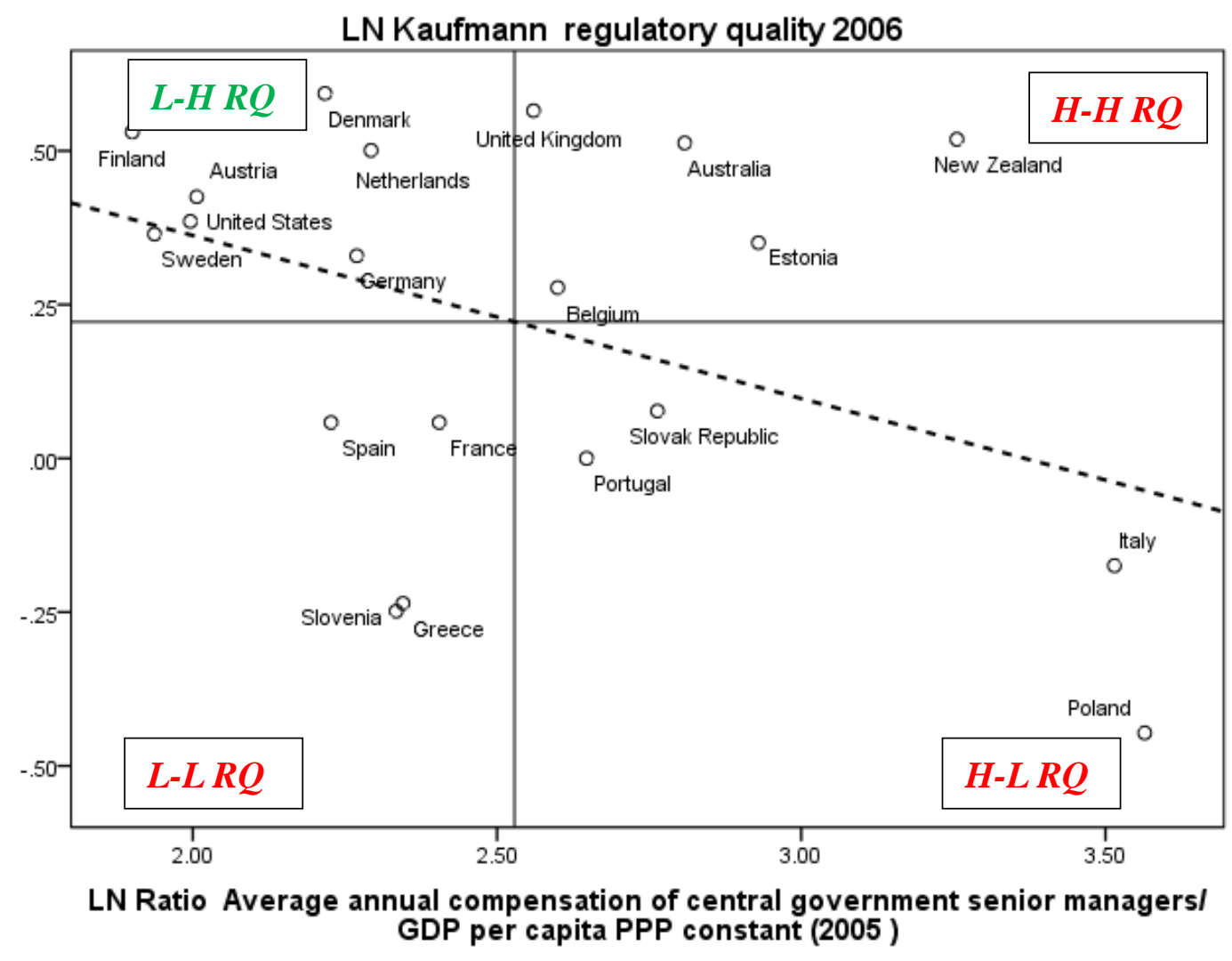

Figure 3. Relationship of Kaufmann regulatory quality on Ratio annual compensation of central government senior managers/ GDP per capita (RCM)

Similar results are for other indicators of governance because of high correlation between variables understudy (see, Table 2). Figure 4 -based on hierarchical cluster with squared Euclidean distance and Ward's method linkage on the variable of Kaufmann government effectiveness - shows three main groups. Table 3 reveals that the group A (Greece, Italy and Poland) has a high average level of the Ratio RCM (annual compensation of central government senior managers/GDP per capita) -i.e. \$26.45- associated with low levels of governance indicators. Group $\mathrm{C}$ reveals countries with a good governance and performance represented by lower levels of the Ratio RCM (annual compensation of central government senior managers/GDP per capita). These results suggest a possible relation between governance of countries and levels of salaries of high public officials. 


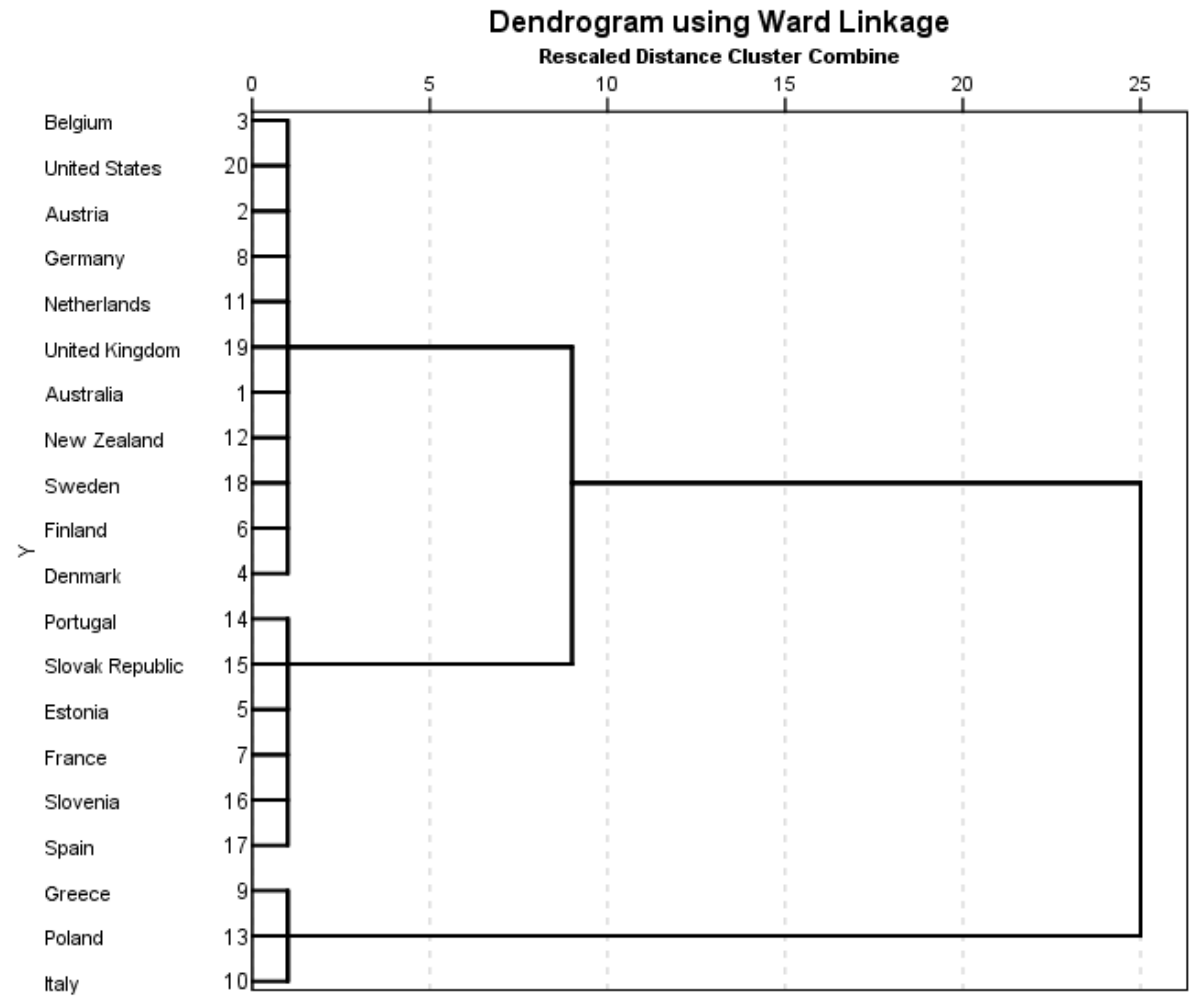

Figure 4. Dendrogram based on Kaufmann government effectiveness 2006 of countries

Table 3. Analysis of groups of countries from dendrogram based on Kaufmann government effectiveness

\begin{tabular}{|c|c|c|c|c|c|c|c|c|}
\hline & & & $\begin{array}{c}\text { Ratio annual } \\
\text { compensation of } \\
\text { central government } \\
\text { senior managers } \\
2011 \text { / GDP per } \\
\text { capita } 2005 \text { (RCM) }\end{array}$ & $\begin{array}{c}\text { Kaufmann } \\
\text { voice } \\
2004\end{array}$ & $\begin{array}{l}\text { Kaufman } \\
\text { rule of } \\
\text { law } \\
2004\end{array}$ & $\begin{array}{c}\text { Kaufmann } \\
\text { corruption } \\
\text { control } \\
2004\end{array}$ & $\begin{array}{c}\text { Kaufmann } \\
\text { government } \\
\text { effectiveness } \\
2006\end{array}$ & $\begin{array}{l}\text { Kaufmann } \\
\text { regulatory } \\
\text { quality } \\
2006\end{array}$ \\
\hline A) & $\begin{array}{l}\mathrm{N} \\
\text { Mean } \\
\text { Std. } \\
\text { Error } \\
\text { Mean }\end{array}$ & of & $\begin{array}{r}3 \\
\mathbf{2 6 . 4 5} \\
8.02\end{array}$ & $\begin{array}{r}3 \\
1.15 \\
0.03\end{array}$ & $\begin{array}{r}3 \\
\mathbf{0 . 6 3} \\
0.11\end{array}$ & $\begin{array}{r}3 \\
\mathbf{0 . 4 2} \\
0.13\end{array}$ & $\begin{array}{r}3 \\
\mathbf{0 . 5 0} \\
0.07\end{array}$ & $\begin{array}{r}3 \\
0.76 \\
0.06\end{array}$ \\
\hline B) & $\begin{array}{l}\mathrm{N} \\
\text { Mean } \\
\text { Std. } \\
\text { Error } \\
\text { Mean }\end{array}$ & of & $\begin{array}{r}6 \\
13.23 \\
1.49\end{array}$ & $\begin{array}{r}6 \\
1.26 \\
0.07\end{array}$ & $\begin{array}{r}6 \\
1.00 \\
0.14\end{array}$ & $\begin{array}{r}6 \\
1.05 \\
0.15\end{array}$ & $\begin{array}{r}6 \\
1.07 \\
0.05\end{array}$ & $\begin{array}{r}6 \\
1.07 \\
0.08\end{array}$ \\
\hline C) & $\begin{array}{l}\mathrm{N} \\
\text { Mean } \\
\text { Std. } \\
\text { Error } \\
\text { Mean }\end{array}$ & & $\begin{array}{r}11 \\
11.46 \\
1.73\end{array}$ & $\begin{array}{r}11 \\
1.61 \\
0.05\end{array}$ & $\begin{array}{r}11 \\
1.78 \\
0.05\end{array}$ & $\begin{array}{r}11 \\
2.08 \\
0.09\end{array}$ & $\begin{array}{r}11 \\
1.85 \\
0.07\end{array}$ & $\begin{array}{r}11 \\
1.58 \\
0.05\end{array}$ \\
\hline
\end{tabular}

Note: Groups: A) Greece, Italy, Poland; B) Portugal, Slovak Rep., Estonia, France, Slovenia, Spain; C) Belgium, USA, Austria, Germany, Netherlands, UK, Australian, New Zealand, Sweden, Finland, Denmark. 


\section{Macrothink}

Journal of Public Administration and Governance

ISSN 2161-7104

2018, Vol. 8, No. 1

Geospatial analysis is based on percentiles of distribution of the association ASC $i\left(\mathrm{RCM}_{i} \times\right.$ 1/Kaufmann Voice and Accountability Index ${ }_{i} \times$ Kaufmann Rule of Law Index $_{i} \times$ 1/Kaufmann Control of Corruption Index $x_{i}$ ). Categories of country $i$ described in the method are given by:

1) $\mathrm{ASC} i \leq 4.87$ (countries with low association, yellow color in the map)

2) $4.87<\mathrm{ASC} i \leq 7.80$ (countries with moderate association, green color)

3) $7.80<\mathrm{ASC} i \leq 13.21$ (countries with high association, red color)

4) $\mathrm{ASC} i>13.21$ (countries with very high association, purple color)

Figure 5 shows the spatial differences of association ASC $i$ between countries.

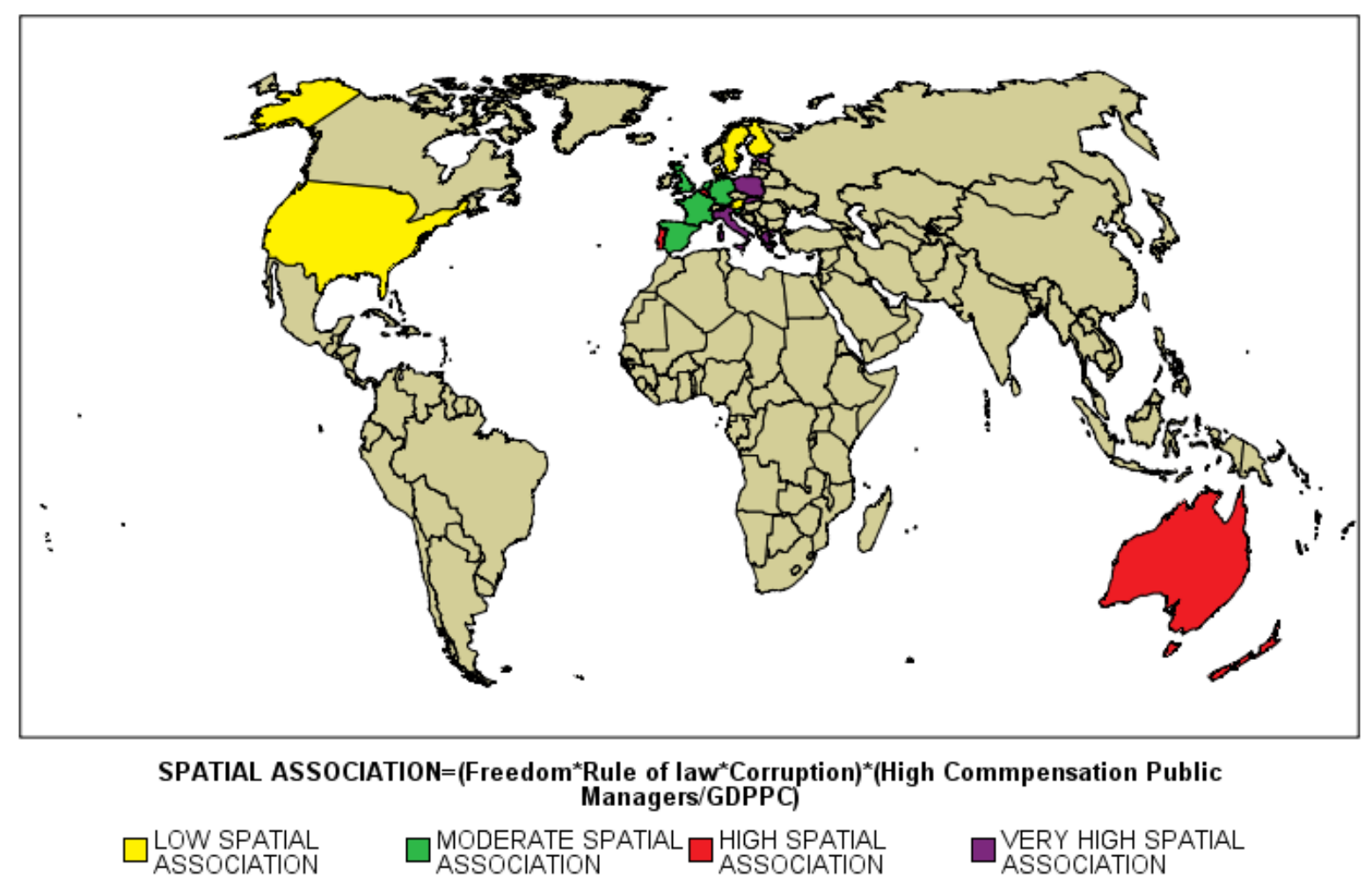

Figure 5. Global distribution of the association of the compensation of public managers combined with governance factors. Note: pale color brown indicates missing values

Very high association (purple color) indicates bad governance factors and problematic economy-wide regulatory environments that can generate inefficiency of public organizations and bureaucracy that possibly support higher annual compensation of public managers. Vice versa, yellow color indicates good governance that may generate fruitful socio-institutional conditions for lower compensation of high public officials. In short, this geospatial analysis of the globe reveals that bad governance of countries seems to be associated with high compensation of public managers in Italy and some countries of the Eastern Europe. Good governance and lower compensation of high public officials seem to be mainly in the USA 
and some Scandinavian Countries. As a matter of fact, in specific countries (i.e., England, Scandinavia, the USA and some OECD countries), public services have an increased pressure of governments to improve their efficiency and to reduce demand on taxpayers, while maintaining the volume and quality of services supplied to the public (Barzelay, 2001; Hood, 1991; Perry, 1996; Witesman and Walters, 2014). Unlike expectation, this geospatial analysis also reveals high levels of RCM in Australia and New Zealand.

\section{Discussion}

Public managers play a central role in public administration, defining what tasks are to be completed and what targets are to be reached to induce high efficiency and effectiveness of countries (Peters and Pierre, 2016; Hood and Dixon, 2015). The statistical evidence here seems to support the hypothesis $\phi$ that on average, high levels of compensation of public managers are associated with bad governance of countries, other things being equal.

On the contrary, countries with lower levels of the ratio annual compensation of central government senior managers/ GDP per capita seem to be associated with a governance environment based on high freedom of expression, freedom of association, free media, low quality of contract enforcement, property rights and corruption control. Studies of the OECD $(2013,2011)$ show that on average, a D1 senior manager's compensation is 3.4 times higher than the average tertiary educated employee's compensation. Results of the study here also reveal that D1 senior managers in Italy, New Zealand and Poland experienced the highest compensation level compared to other countries (levels standardized with GDP per capita). However, high levels of compensation can also result from differences in national labor markets, laws of public contracts, power of trade unions and remuneration of the private sector for comparable skills (cf., Hubbard, 2005).

The results here show the importance of good governance mechanisms for improving economy-wide regulatory environments that can create rule of law to support more equity in levels of compensation of public managers (cf., Friedman, 2008). As a matter of fact, bad governance and inefficient economy-wide regulatory environments of countries can explain high levels of compensation of central government senior managers and also low efficiency of overall public administration. In order to control (and also reduce) the high compensation of public managers and increase government effectiveness of nations, some reforms require that public administration should introduce systems of evaluation, incentives and rewards (extrinsic and intrinsic) associated with performances, achievements and merit of individuals (Capano, 2003, Coccia, 2001; Ongaro and Valotti, 2008, Benati and Coccia, 2018). However, the study here suggests that a vital role to reduce and control the level and growth of the compensation of high public officials is also due to good governance within countries. In particular, the creation of environments with more democratization and control of corruption, low bureaucratization and better governance can create fruitful conditions to mitigate the level of salary of public managers and also favor the efficiency and performance of the whole public sector (cf., Coccia, 2009; 2009a for public research labs and Coccia, 2016 for private firms). Hence, many changes and reforms directed to improve general governance should be implemented in several countries that have low government effectiveness and regulatory 
quality associated with high compensation of public managers in order to enhance the overall efficiency of public administration (cf., Ongaro, 2011; Ongaro and Valotti, 2008 for Italy and other countries).

\section{Concluding Observations}

Statistical analysis presented in this paper suggests that in average, low levels of governance within countries are associated with high levels of senior public manager's compensation. Put it differently, virtuous countries in terms of good governance have also lower senior public managers' salaries, while countries with bad governance tend to have, in average, higher ones. This finding shows that the reduction in the cost of public administration goes through a country's overall governance improvement. Public management reforms based on manager's salary reduction policies and/or better rewards (pay-for-performance), in a context of bad governance, cannot produce the expected results. These policies should be associated with general reforms of governance in order to improve economy-wide regulatory environment and labor market, competition and transparency in the public administration, control corruption and democratization of nations. In particular, good governance should integrate principles that enable to guarantee the greatest possible democratic status and the efficient conduct of public administration and quality of government (Rothstein and Teorell, 2008). Moreover, the principles of good governance should foster good functioning of governance networks and enable them to achieve their goals, such as transparency, participation, accountability, and effectiveness. Peters (2008) links this result to the relation between coordination and coherence. Others scholars also include the principle of impartiality (Rothstein and Teorell 2008). However, defining the principles of good governance is difficult (Graham et al. 2003) and there is not an agreement about the utility of this concept and its role to foster democracy and development (Andrews 2010).

Results here can be also important to design appropriate best practices, in context of good governance factors, in quest of a greater efficiency in public administration (such as, design a reward scheme based on flexible salaries of public managers, etc.; $c f$. ., Cassandro, 1979; Coccia and Rolfo, 2013). Appropriate public policies for supporting equity in the compensation of managers, of course, are due to manifold factors. For instance, in the city-state of Singapour, the high salary in public administration is used to attract competent managers to work for the government and create a competition with compensation of private sectors. Hence, much work remains to understand the general implications of governance on levels of compensation of managers in public administration within and between countries. This study shows the importance of some governance factors but detailed analyses depend on data accessible to explain general patterns of governance, of public performance and of salaries for high public officials within and between countries. Especially limiting is that the sample under study here is small due to the lack of data for several countries. Hence, more efforts to record currently unmeasured aspects of the compensation and performance of public managers as well as factors of economy-wide regulatory environments and governance of countries should be a priority. Collecting more data in these topics obviously involves costs, but there is much to be gained for designing best practices and reforms directed to improve the overall governance and public administration of countries. 


\section{$\Lambda$ Macrothink}

Journal of Public Administration and Governance

ISSN 2161-7104 2018, Vol. 8, No. 1

To conclude, this preliminary study may form a ground work for development of more sophisticated theoretical and empirical analyses to explain possible general causes of the high levels of salary of public managers associated with socioeconomic, political, institutional and governance factors. This study seems to show that high levels of public manager compensation are associated with low levels of government effectiveness and regulatory quality, combined with low freedom of expression, freedom of association, free media, quality of contract enforcement, property rights and corruption control. However, the conclusions of this study here are, of course, tentative. There is need for much more detailed research and large samples to explain the complex relation between compensation for high public officials, governance and economy-wide regulatory factors between countries.

\section{Acknowledgement}

We gratefully acknowledge financial support from the National Research Council of Italy. Mario Coccia acknowledges financial support from the CNR - National Research Council of Italy for the visiting at Arizona State University (Grant n. 0003005-2016) where this research started in 2017. We are also grateful to Secondo Rolfo for fruitful suggestions and comments. The authors declare that they have no relevant or material financial interests that relate to the research discussed in this paper.

\section{References}

Acemoglu, D. (2008). Interactions between Governance and Growth. In Governance, growth, and development decision-making. Washington, DC: World Bank.

Andrews, M. (2010). Good Government Means Different Things in Different Countries. Governance, 23(1), 7-35. https://doi.org/10.1111/j.1468-0491.2009.01465.x

Barzelay, M. (2001). The new public management: improving research and policy dialogue. Berkeley : New York: University of California Press : Russell Sage Foundation.

Benati, I., \& Coccia, M. (2017). General Trends and Causes of High Compensation of Government Managers in the OECD Countries. International Journal of Public Administration, 1-14. https://doi.org/10.1080/01900692.2017.1318399

Benati, I., \& Coccia, M. (2018). Rewards in Bureaucracy and Politics. Global Encyclopedia of Public Administration, Public Policy, and Governance -section Bureaucracy (edited by Ali Farazmand). Springer International Publishing AG. Chapter No.: 3417-1, https://doi.org/10.1007/978-3-319-31816-5_3417-1

Bozeman, B. (2007). Public values and public interest: counterbalancing economic individualism. Washington, D.C.: Georgetown University Press. http://public.eblib.com/choice/publicfullrecord.aspx?p=547786

Brans, M., \& Peters, B. G. (A c. di). (2012). Rewards for high public office in Europe and North America. New York: Routledge. 


\section{Macrothink}

Journal of Public Administration and Governance ISSN 2161-7104 2018, Vol. 8, No. 1

Butkiewicz, J. L., \& Yanikkaya, H. (2011). Institutions and the Impact of Government Spending on Growth. Journal of Applied Economics, 14(2), 319-341. https://doi.org/10.1016/S1514-0326(11)60017-2

Capano, G. (2003). Administrative Traditions and Policy Change: When Policy Paradigms Matter. The Case of Italian Administrative Reform During the 1990s. Public Administration, 81(4), 781-801. https://doi.org/10.1111/j.0033-3298.2003.00371.x

Cassandro, P. E. (1979). Le aziende erogatrici pubbliche, Torino, Italy: UTET.

Chen, C. A., \& Bozeman, B. (2014). Am I a Public Servant or Am I a Pathogen? Public Managers' Sector Comparison of Worker Abilities: Public Managers' Sector Comparison of Worker Abilities. Public Administration, n/a-n/a. https://doi.org/10.1111/padm.12034

Coccia, M. (2001). Satisfaction, work involvement and R\&D performance. International Journal of Human Resources Development and Management, 1(2/3/4), 268. https://doi.org/10.1504/IJHRDM.2001.001010

Coccia, M. (2005). Countrymetrics: valutazione della performance economica e tecnologica dei paesi e posizionamento dell'Italia. Rivista Internazionale di Scienze Sociali, 113(3), 377-412. http://www.jstor.org/stable/41624216

Coccia, M. (2007). A new taxonomy of country performance and risk based on economic and technological indicators. Journal of Applied Economics, 10(1), 29-42. Available at SSRN: https://ssrn.com/abstract=2578025

Coccia, M. (2009). Bureaucratization in Public Research Institutions. Minerva, 47(1), 31-50. https://doi.org/10.1007/s11024-008-9113-z

Coccia, M. (2009a). Research performance and bureaucracy within public research labs. Scientometrics, 79(1), 93-107. https://doi.org/10.1007/s11192-009-0406-2

Coccia, M. (2009b). A New Approach for Measuring and Analysing Patterns of Regional Economic Growth: Empirical Analysis in Italy. Italian Journal of Regional Science- Scienze Regionali, 8(2), 71-95. https://doi.org/10.3280/SCRE2009-002004

Coccia, M. (2010). Public and private R\&D investments as complementary inputs for productivity growth. International Journal of Technology, Policy and Management, 10(1/2), 73. https://doi.org/10.1504/IJTPM.2010.032855

Coccia, M. (2010a). Democratization is the driving force for technological and economic change. Technological Forecasting and Social Change, 77(2), 248-264. https://doi.org/10.1016/j.techfore.2009.06.007

Coccia, M. (2013). What are the likely interactions among innovation, government debt, and employment? Innovation: The European Journal of Social Science Research, 26(4), 456-471. https://doi.org/10.1080/13511610.2013.863704 


\section{Mll Macrothink}

Journal of Public Administration and Governance ISSN 2161-7104 2018, Vol. 8, No. 1

Coccia, M. (2014). Structure and organisational behaviour of public research institutions under unstable growth of human resources. International Journal of Services Technology and Management, 20(4/5/6), 251. https://doi.org/10.1504/IJSTM.2014.068857

Coccia, M. (2016). Radical innovations as drivers of breakthroughs: characteristics and properties of the management of technology leading to superior organisational performance in the discovery process of R\&D labs. Technology Analysis \& Strategic Management, 28(4), 381-395. https://doi.org/10.1080/09537325.2015.1095287

Coccia, M. (2017). Asymmetric paths of public debts and of general government deficits across countries within and outside the European monetary unification and economic policy of debt dissolution. The Journal of Economic Asymmetries, 15, 17-31. https://doi.org/10.1016/j.jeca.2016.10.003

Coccia, M. (2017a). Optimization in R\&D intensity and tax on corporate profits for supporting labor productivity of nations. The Journal of Technology Transfer. https://doi.org/10.1007/s10961-017-9572-1

Coccia, M., \& Benati, I. (2017). What is the relation between public manager compensation and government effectiveness? An explorative analysis with public management implications. Quaderni Ircres-CNR, 2(2), 1-36, https://doi.org/10.23760/2499-6661.2017.001

Coccia M., \& Benati, I. (2018). Comparative Studies. Global Encyclopedia of Public Administration, Public Policy, and Governance -section Bureaucracy (edited by Ali Farazmand), Springer International Publishing AG, Cham. Chapter No. 1197-1, 1-7, https://doi.org/10.1007/978-3-319-31816-5_1197-1

Coccia, M., \& Cadario, E. (2014). Organisational (un)learning of public research labs in turbulent context. International Journal of Innovation and Learning, 15(2), 115. https://doi.org/10.1504/IJIL.2014.059756

Coccia, M., \& Rolfo, S. (2007). How research policy changes can affect the organization and productivity of public research institutes: An analysis within the Italian national system of innovation. Journal of Comparative Policy Analysis: Research and Practice, 9(3), 215-233. https://doi.org/10.1080/13876980701494624

Coccia, M., \& Rolfo, S. (2009). Project management in public research organisations: strategic change in complex scenarios. International Journal of Project Organisation and Management, 1(3), 235. https://doi.org/10.1504/IJPOM.2009.027537

Coccia, M., \& Rolfo, S. (2010). New entrepreneurial behaviour of public research organisations: opportunities and threats of technological services supply. International Journal of Services Technology and Management, 13(1/2), 134. https://doi.org/10.1504/IJSTM.2010.029674

Coccia, M., \& Rolfo, S. (2013). Human Resource Management and Organizational Behavior of Public Research Institutions. International Journal of Public Administration, 36(4), 256-268. https://doi.org/10.1080/01900692.2012.756889 


\section{Macrothink}

Journal of Public Administration and Governance ISSN 2161-7104 2018, Vol. 8, No. 1

Denis, D. J., Denis, D. K., \& Sarin, A. (1997). Ownership structure and top executive turnover. Journal of Financial Economics, 45(2), 193-221. https://doi.org/10.1016/S0304-405X(97)00016-0

Dittmann, I., Maug, E., \& Zhang, D. (2011). Restricting CEO pay (Vol. 17). http://linkinghub.elsevier.com/retrieve/pii/S0929119911000484

Friedman, M. (2008). Living wage and optimal inequality in a Sarkarian framework. Review of Social Economy, 66(1), 93-111. https://doi.org/10.1080/00346760701668479

Fukuyama, F. (2013). What is Governance? SSRN Electronic Journal. https://doi.org/10.2139/ssrn.2226592

Gao, H., \& Li, K. (2015). A comparison of CEO pay-performance sensitivity in privately-held and public firms. Journal of Corporate Finance, 35, 370-388. https://doi.org/10.1016/j.jcorpfin.2015.10.005

Gisselquist, R. M. (2012). Good governance as a concept, and why this matters for development policy.

Helsinki:

WIDER.

http://www.wider.unu.edu/publications/working-papers/2012/en_GB/wp2012-030/

Gisselquist, R. M. (2014). Developing and evaluating governance indexes: 10 questions. Policy Studies, 35(5), 513-531. https://doi.org/10.1080/01442872.2014.946484

Graham, J., Amos, B., \& Plumptre, T. (2003). Principles for good governance in the 21st century. Policy Brief 15, 1-6. www.iog.ca/publications/policy briefs

Hood, C. (1991). A Public Management for All Seasons? Public Administration, 69(1), 3-19. https://doi.org/10.1111/j.1467-9299.1991.tb00779.x

Hood, C., \& Dixon, R. (2015). A government that worked better and cost less? Evaluating three decades of reform and change in UK central government (First Edition). Oxford, United Kingdom; New York, NY: Oxford University Press. https://doi.org/10.1093/acprof:oso/9780199687022.001.0001

Hood, C., \& Lodge, M. (2006). The Politics of Public Service Bargains. Oxford University Press. https://doi.org/10.1093/019926967X.001.0001

Hood, C., \& Peters, B. G. (A c. di). (1994). Rewards at the top: a comparative study of high public office. London; Thousand Oaks, Calif: Sage.

Hood, C., \& Peters, B. G. (A c. di). (2003). Reward for high public office: Asian and Pacific-rim states. London: Routledge.

Hubbard, R. G. (2005). Pay without Performance: A Market Equilibrium Critique. SSRN Electronic Journal. https://doi.org/10.2139/ssrn.868513

Jarque, A. (2008). CEO compensation: Trends market changes, and regulation, Economic Quarterly, 94(3), 265-300. https://ssrn.com/abstract=2187869 
Kaufmann, D., Kraay, A., \& Zoido, L. P. (1999). Governance matters. World Bank Policy Research Working Paper No 2196. Washington DC: World Bank. https://econpapers.repec.org/paper/wbkwbrwps/2196.htm

Kaufmann, D., Kraay, A., \& Mastruzzi, M. (2005). Governance Matters IV: Governance Indicators for 1996-2004. World Bank Policy Research Working Paper No. 3630. Washington DC. https://doi.org/10.1596/1813-9450-3630

Kaufmann, D., Kraay, A., \& Mastruzzi, M. (2008). Governance Matters VII: Aggregate and Individual Governance Indicators, 1996-2007. SSRN Electronic Journal. https://doi.org/10.2139/ssrn.1148386

Kaufmann, D., Kraay, A., \& Mastruzzi, M. (2010). The Worldwide Governance Indicators: Methodology and Analytical Issues (September 2010). World Bank Policy Research Working Paper No. 5430. Available at SSRN: https://ssrn.com/abstract=1682130

Keser, A., \& Gökmen, Y. (2018). Governance and Human Development: The Impacts of Governance Indicators on Human Development. Journal of Public Administration and Governance, 8(1), 26. https://doi.org/10.5296/jpag.v8i1.12336

Khan, M. H. (2009) Building Growth Promoting Governance, UNCTAD Background paper, n.2/2009

Kuhnen, C. M., \& Niessen, A. (2012). Public Opinion and Executive Compensation. Management Science, 58(7), 1249-1272. https://doi.org/10.1287/mnsc.1110.1490

Malul, M., \& Shoham, A. (2013). The salaries of CEOs: Is it all about skills? Journal of Economics and Business, 67, 67-76. https://doi.org/10.1016/j.jeconbus.2013.03.003

Meier, K. J., \& O’Toole, L. J. (2010). Beware of Managers Not Bearing Gifts: How Management Capacity Augments the Impact of Managerial Networking. Public Administration, 88(4), 1025-1044. https://doi.org/10.1111/j.1467-9299.2010.01853.x

Norris, P. (2008). Democracy Time Series Dataset, Harvard Kennedy School, Cambridge, MA.

North, D., Acemoglu, D., Fukuyama, F., \& Rodrik, D. (eds) (2008). Governance, growth, and development decision-making. The World Bank, Washington, DC

OECD. (2011). Public Servants as Partners for Growth: Toward a Stronger, Leaner and More Equitable Workforce. Paris: OECD Publishing. ISBN Number: 9789264166707

OECD. (2012). Public Sector Compensation in Times of Austerity. Paris: OECD Publishing. https://doi.org/10.1787/9789264177758-en

OECD. (2013). Government at a Glance 2013. OECD Publishing. https://doi.org/10.1787/gov_glance-2013-en 
Ongaro, E. (2011). The Role of Politics and Institutions in The Italian Administrative Reform $\begin{array}{llll}\text { Trajectory. } & \text { Public } & \text { Administration, } & \text { 738(3), }\end{array}$ https://doi.org/10.1111/j.1467-9299.2010.01885.x

Ongaro, E., \& Valotti, G. (2008). Public management reform in Italy: explaining the implementation gap. International Journal of Public Sector Management, 21(2), 174-204. https://doi.org/10.1108/09513550810855654

Perry, J. L. (1996). Measuring Public Service Motivation: An Assessment of Construct Reliability and Validity. Journal of Public Administration Research and Theory, 6(1), 5-22. https://doi.org/10.1093/oxfordjournals.jpart.a024303

Peters, B. (2009). The Two Futures of Governing: Decentering and Recentering Processes in Governing. NISPAcee Journal of Public Administration and Policy, 2(1). https://doi.org/10.2478/v10110-009-0002-0

Peters, B. G., \& Pierre, J. (2016). Comparative Governance: Rediscovering the Functional Dimension of Governing. Cambridge: Cambridge University Press. https://doi.org/10.1017/CBO9781316681725

Rimington, J. D. (2008). The Value of the Remuneration of High Civil Servants in Britain in The 20th Century and Its Implications. Public Administration, 86(4), 1107-1127. https://doi.org/10.1111/j.1467-9299.2008.00739.x

Rothstein, B., \& Teorell, J. (2008). What Is Quality of Government? A Theory of Impartial Government Institutions. Governance, 21(2), 165-190. https://doi.org/10.1111/j.1468-0491.2008.00391.x

Thomas, M. A. (2010). What Do the Worldwide Governance Indicators Measure? The European Journal of Development Research, 22(1), 31-54. https://doi.org/10.1057/ejdr.2009.32

WGI. (2010). Worldwide Governance Indicators, Access the WGI data at www.govindicators.org

Witesman, E., \& Walters, L. (2014). Public Service Values: A New Approach to the Study of Motivation in the Public Sphere: Public Service Values. Public Administration, 92(2), 375-405. https://doi.org/10.1111/padm.12000

World Bank. (1992). Governance and development, Washington, DC: The World Bank

World Bank. (2008). World development indicators, http://data.worldbank.org/data-catalog/world-development-indicators

World Bank. (2017). World development report, Governance and the Law. The World Bank Group, Washington, DC: The World Bank 


\section{Copyright Disclaimer}

Copyright for this article is retained by the author(s), with first publication rights granted to the journal.

This is an open-access article distributed under the terms and conditions of the Creative Commons Attribution license (http://creativecommons.org/licenses/by/4.0/). 